\title{
プロジェクト報告「複合機能化への材料協調設計」
}

\section{双結晶を利用した複合機能化のための 界面制御}

\author{
馬越佑吉* 安田弘行** 上田正人*** 坂田利弥***
}

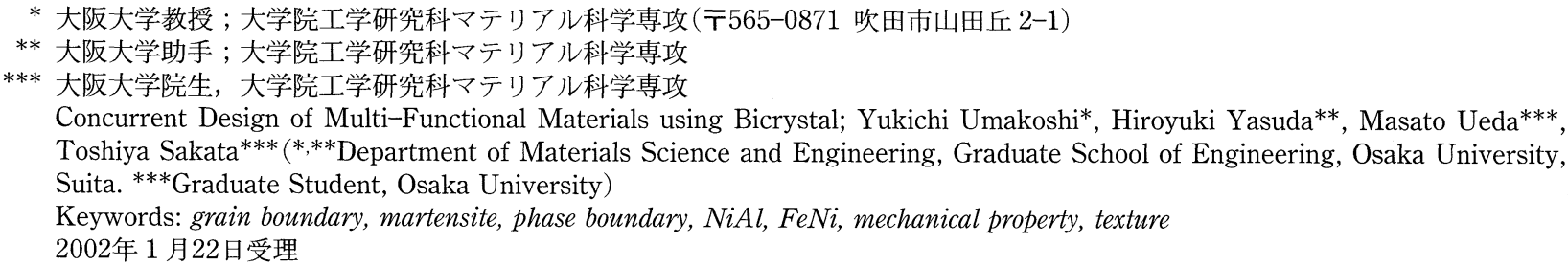

1. は じめに

実用材料の多くは多結晶として使用され，その力学特性な らびに機能特性は必然的に存在する結晶粒界性格に強く依存 する. 力学特性について見れば，結晶粒界は転位の運動抵抗 として働き強化に寄与するが，金属間化合物などではしばし ば粒界脆化をもたらし，脆さの原因となる ${ }^{(1)}$ 。この粒界脆化 の抑止策として粒界性格制御ならびに界面に析出する第二相 の形態，構造制御が重要である.

マルテンサイト $(\mathrm{M})$ 変態は, 力学特性の改善を初め, 形状 記憶効果なぞ機能特性発現に重要な役割を果たす。結晶粒界 は, この $\mathrm{M}$ 変態の優先核生成サイトとして働き(2), 機能材 料の複合化，機能向上のためには，粒界・界面近傍における $\mathrm{M}$ 変態挙動の解明が重要となる.この $\mathrm{M}$ 晶の形態, 変態開 始温度 $(\mathrm{Ms})$ ならびに兄弟晶の選択性の粒界性格依存性を明 らかにし，これを利用した粒界設計による様々な用途に対応 し得る機能特性制御が可能となる.

本稿では粒界性格を制御した双結晶を用い， NiAl 合金の 粒界析出第二相の形態制御, 界面制御による力学特性改 善(3)(4), FeNi 合金のマルテンサイト変態に及ぼす粒界の役 割, $\mathrm{M}$ 晶の形態, 兄弟晶選択性に及ぼす負荷応力等の外的 因子の役割(5)(6)を紹介し, 材料協調設計への粒界構造の寄与 を明らかにする。

\section{2． FeNi 合金の M 変態に及ぼす粒界の役割}

$\mathrm{Fe}-32$ at $\% \mathrm{Ni}$ 合金単結晶より拡散接合により図 1 に示す ような $90^{\circ}\langle 211\rangle$ 対称傾角粒界， $90^{\circ}\{211\}$ ねじり粒界を有す る双結晶を作製した．引張軸が〈941〉になるような単結晶な
らびに双結晶について，電気抵抗変化より求めた Ms 点と応 力誘起 $M$ 変態の $M s$ と負荷応力との関係を図 2 に示す. 熱 誘起 $\mathrm{M}$ 変態について見ると, 単結晶に比べて傾角粒界双結 晶は Ms 点が明らかに上昇している(5)． $\gamma$ 母相弾性限内で変 態した場合, いずれの結晶も応力負荷により Ms 点は上昇 し，熱誘起 $\mathrm{M}$ 変態と同様に顕著な結晶タイプ依存性が認め られた．単結晶および傾角粒界双結晶ともにMs 点は無負荷 状態を起点として応力増加に伴って直線的に増加するが，そ の勾配は傾角粒界の方が急である。一方，ねじり粒界の Ms には明瞭な直線関係は認められず，単結晶と傾角粒界の中間 に位置している．ねじり粒界は熱誘起 $M$ 変態において，単 結晶に対しての核生成の有利性は認められず，また一軸応力 負荷状態での Ms 点は単結晶部のそれと大きく違わなく，核 生成が粒内であるか, 粒界であるかに依存して Ms 点がばら つ<

熱誘起 $M$ 晶の形態を見ると，図 3 に示すように単結晶で は均一核生成し，傾角粒界では粒界を起点として $\mathrm{M}$ 晶が粒 界に対し対称に生成しており，粒界が $\mathrm{M}$ 晶の優先核生成サ イトとして働いていることを示唆している，応力負荷条件下 では， $M$ 晶は粗大化するが，その形態は殆ど同じである，

一方，ねじり粒界双結晶の熱誘起変態では粒界が核生成サイ トとして有効に働かないため，単結晶に類似した均一核生成 組織を示すが, 応力負荷条件下では粒界部の応力集中などに より，粒界が核生成に寄与するようになる ${ }^{(6)}$ 。さて， FeNi 合金の $\mathrm{M}$ 変態は，結晶構造について見れば，fcc から bcc への構造変換であり， $\mathrm{M}$ 晶と $\gamma$ 相との間には，(111) $\gamma / /$ $(011)_{\alpha},[\overline{1} \overline{1} 2]_{\gamma} / /[0 \overline{1} 1]_{\alpha}$ なる Nishiyama-Wassermann $(\mathrm{N}-$ $\mathrm{W})$ の方位関係を示し，V1〜V12, V1'〜V12'で表示される 24 種類の晶癖面兄弟晶に分類される(7)。単結晶中に現れる $\mathrm{M}$ 晶について SEM-EBSP 法を用いその方位関係を調べる 


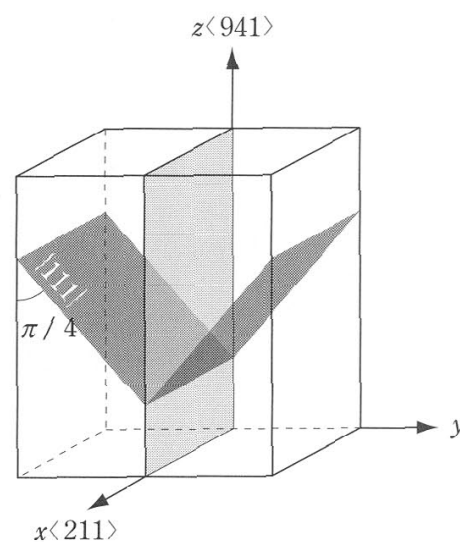

(a) $90^{\circ}<211>$ 傾角粒界

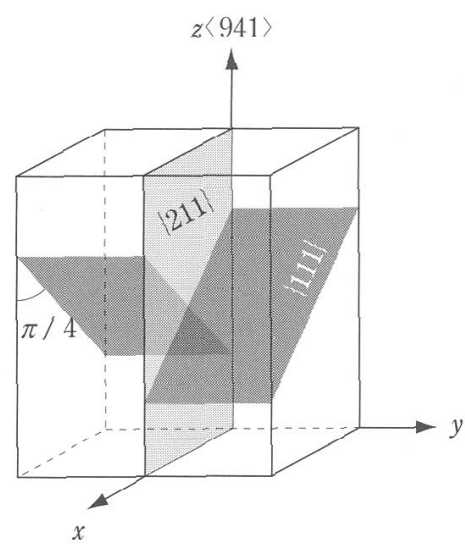

(b) $90^{\circ}\{211\}$ ねじり粒界

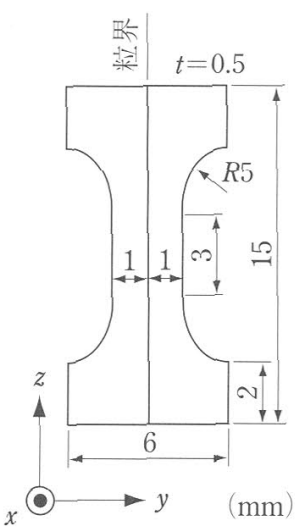

(c) 引張試験片サイズ

図 $1 \mathrm{FeNi}$ 双結晶の方位関係と試料形状.

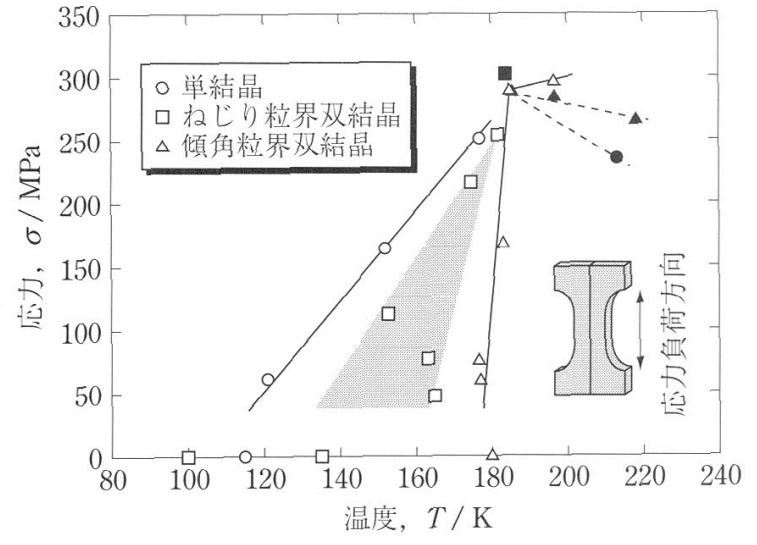

図 $2 \mathrm{FeNi}$ 単結晶, 双結晶の $\mathrm{Ms}$ 点の負荷応力依存性.

と, 24 種類の兄弟晶がほぼ等価に現れる. 一方, 双結晶の 粒界近傍では図 4 に示すように兄弟晶の選択性が生じ, 傾角 粒界近傍ではV11とV2'が両結晶中に粒界に対し対称に生成 する。しかし，放じり粒界では多くの兄弟晶が生成して拧 り，粒界近傍に注目すると V8, V9'，V8 および V7 が選択さ れるが，両構成結晶中で対称性は認められない，このような 傾角粒界近傍の兄弟晶選択性は応力付加条件下でも認められ， V11に加えてV12, V3'も現れる.

さて，粒界の性格によってなぜこのように Ms 点が変化 し, 兄弟晶の選択性が違うのであろうか. いま $\mathrm{M}$ 変態が核 生成・成長の二段階で起こり，核生成弾純な $\mathrm{fcc} \rightarrow \mathrm{bcc} の$ Bain 変形であると仮定する。双結晶を構成する成分結晶に ついて Bain 変形に伴う歪テンソルを比較すると，傾角粒界 では同じグループに属する Bain 変形では各成分結晶の歪テ ソソルは完全に等価となるが，ねじり粒界では完全に等価上 なるものはない，粒界の歪の連続性に注目すると，傾角粒界 では図 5 (a)に示すように同じグループ，本試料の場合は V11が粒界を介して隣接すれば，粒界面上の変位は連続とな り，粒界はＭ変態の抵抗とならず核生成サイトとして㗢く ため，Ms点は著しく上昇する。一方，ねじり粒界の場合， いず狆のグループが隣接したとしても各歪成分が完全に一致 する場合はなく，図 5(b)のようになり粒界が $\mathrm{M}$ 変態の抵抗 となる。

次に応力負荷条件下の M 変態在考光る. Goodchild $5^{(8)}$
は，荷重軸と晶癖面とのなす角 $\theta$ ならびに荷重軸とせん断方 向のなす角 $\lambda$ を用いて, 一軸応力 $\sigma$ が $\mathrm{M}$ 変態を助長する工 ネルギーUを次式で与えた。

$$
U / \sigma=\gamma \cos \theta \cos \lambda+\varepsilon \cos ^{2} \theta
$$

ここで， $\varepsilon$ と $\gamma$ はそれぞれ晶癖面に垂直ならびに平行な変態 歪である. 表 1 に各兄弟晶についての $(U / \sigma)$ 值を示寸. 正の 大きい値であれば一軸引張応力で兄弟晶は核生成が助長さ れ，逆に負であれば抑制される。ねじり粒界双結晶ではV5 やV8'といった正の大きい $(U / \sigma)$ 值を有するバリアントが選 択された。一方，傾角粒界では $(U / \sigma)$ 值の小さいV11が生 成した。これは応力の効果よりも粒界近傍の歪の連続性が優 先するためである。単結晶では 24 種類の兄弟晶の中で一軸 応力負荷が最も効果的に寄与する兄弟晶が誘起されるため, $\mathrm{Ms}$ 点の応力依存性が大きくなる。一方, 傾角粒界では Ms 点に寄与するV11兄弟晶への応力の寄与は小さく，そのた め Ms 点は殆ど変化しない。

このように傾角粒界は M 変態の優先核生成サイトとして 働き, 極めて強い兄弟晶選択性を示す。この $\mathrm{M}$ 変態の粒界 性格依存性を考慮し, 加工・熱処理により粒界制御を行え ば，その用途に応じた機能特性の制御も可能となる。

\section{NiAl 合金の粒界析出相の界面制御之粒界脆化の 抑制}

B2 型金属間化合物 $\operatorname{NiAl}(\beta)$ は, 高融点かつ優れた高温 強度を有するとともに良好な耐酸化性を示すため, $\mathrm{L}_{2}$ 型 $\mathrm{Ni}_{3} \mathrm{Al}\left(\gamma^{\prime}\right)$ に代わる耐熱材料として実用化が期待されてい る(9). しかし, 低温での变形能の欠如, とりわけ粒界脆化が 問題となる。 その解決策の一つとして, 低温で良好な变形能 を示し, 優れた高温強度を有する $\gamma^{\prime}$ 相を粒界にフィルム状 に析出させ， $\beta / \gamma^{\prime}$ 両相の優れた特性を生かした材料協調設計 を図る (3) (4). $\beta$ 相からの $\gamma^{\prime}$ 相の析出, すなわち $\mathrm{fcc} \rightarrow \mathrm{bcc}$ 構 造変換の際の Kurdjumov-Sachs (K-S) 関係に注目し(10)(11), $\beta / \gamma^{\prime}$ 界面構造の制御と異相界面強度と構造との関係を調べ, 力学特性改善への指針を得万.

$\mathrm{Ni}-38$ at\% A1 単結晶老 $\beta$ 単相化熱処理後, 図 6(a)のよう な所定の方位関係の $\beta(1)$ および $\beta(2)$ 成分結晶を拡散接合し, $\mathrm{NiAl}$ 双結晶を得る。 $\beta(1)$ 結晶は接合面法線を〈110〉に固定 

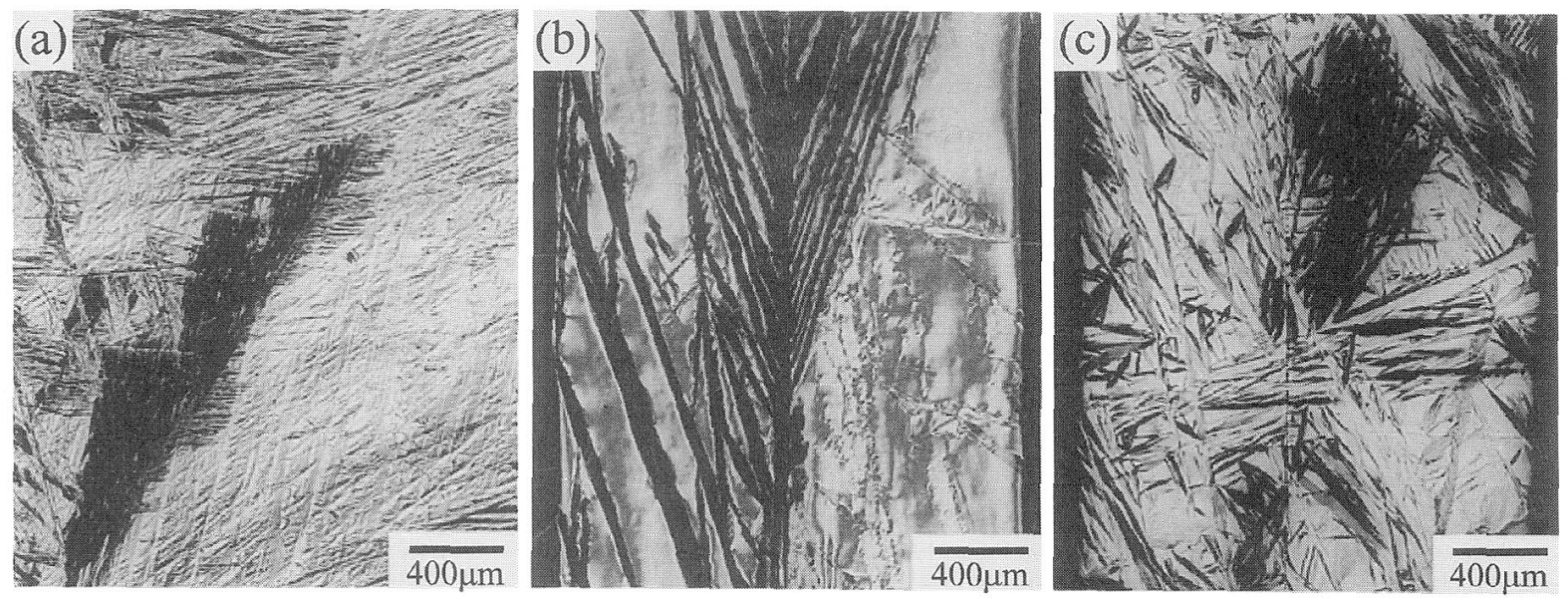

図 3 FeNi 単結晶および双結晶の熱誘起マルテンサイト組織.

(a) 単結晶，（b）傾角粒界双結晶，（c）ねじり粒界双結晶.
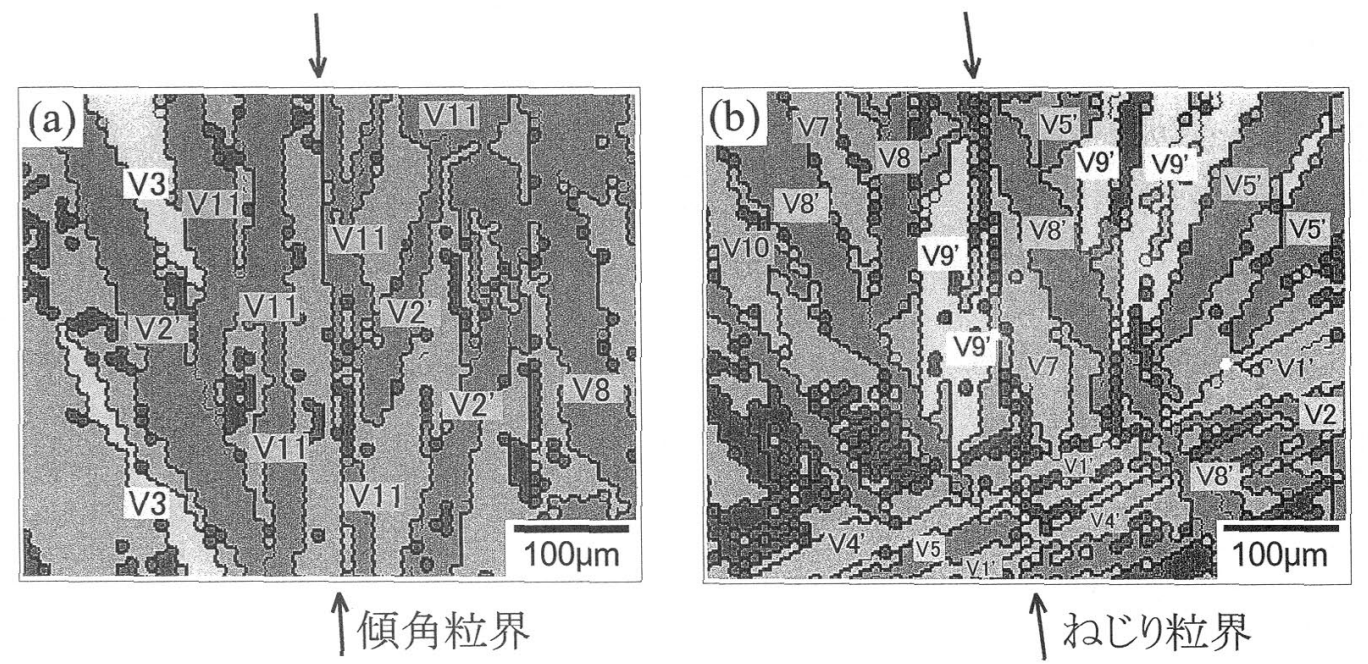

図 4 FeNi 双結晶の EBSP 像と兄弟晶.

（a）傾角粒界双結晶，（b）ねじり粒界双結晶.

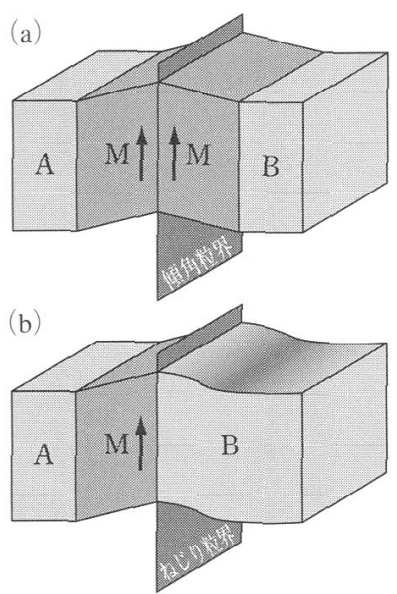

図 $5 \mathrm{FeNi}$ 双結晶の粒界に打けるマルテンサイト変態 に伴う歪みの連続性に関する模式図.

(a) 傾角粒界双結晶，（b）ねじり粒界双結晶.

L, $\beta(2)$ の接合面法線は $\langle 100\rangle,\langle 110\rangle,\langle 111\rangle$ 等に变化させ るとともに， $\beta(1)$ 結晶 $の\langle 100\rangle$ に対し， $\beta(2) の\langle 100\rangle,\langle 110\rangle$, 〈111〉方向を様々な角度まで回転し, 双結晶粒界面の方位を 変化させた。この双結晶 $\left(\beta / \gamma^{\prime}\right)$ を二相領域の $1073 \mathrm{~K}$ で24時 間焼鈍し， $\beta$ 粒界にフィルム状 $\gamma^{\prime}$ を析出させた。この際
表 1 各兄弟晶に対する $U / \sigma$ 值.

\begin{tabular}{|c|c|c|c|}
\hline 兄弟晶 & $U / \sigma$ 値 & 兄弟晶 & $U / \sigma$ 值 \\
\hline V1 & -0.0977 & $\mathrm{~V} 1^{\prime}$ & -0.0637 \\
\hline $\mathrm{V} 2$ & 0.0787 & $\mathrm{~V} 2^{\prime}$ & -0.0397 \\
\hline V3 & 0.0159 & V3' & 0.100 \\
\hline V4 & -0.103 & V4' & 0.0745 \\
\hline V5 & 0.0729 & V5' & -0.0430 \\
\hline V6 & 0.00374 & $\mathrm{~V} 6^{\prime}$ & 0.0913 \\
\hline V7 & -0.0468 & $\mathrm{~V} 7^{\prime}$ & -0.0577 \\
\hline V8 & -0.00113 & V8' & 0.0922 \\
\hline V9 & 0.101 & V9' & 0.0190 \\
\hline V10 & -0.0599 & V10' & -0.0616 \\
\hline $\mathrm{V} 11$ & -0.0004 & V11' & 0.0954 \\
\hline V12 & 0.101 & $\mathrm{~V} 12^{\prime}$ & 0.0108 \\
\hline
\end{tabular}

$\beta(1)$ の (10) 面に $\gamma^{\prime}$ 相の (111)面が沿つて図 6(b)のように析 出するため $\beta(1) / \gamma^{\prime}$ 界面は $\beta(1)$ の (1̄10) 面に $\gamma^{\prime}$ 相の (111) 面 が $(1 \overline{1} 0)_{\beta(1)} / /(111)_{\gamma^{\prime}} ;[\overline{1} 11]_{\beta(1)} / /[1 \overline{1} 0]_{\gamma^{\prime}}$ なる $\mathrm{K}-\mathrm{S}$ 関係を満 足した整合界面を形成する。一方， $\beta(2) / \gamma^{\prime}$ 界面は $\beta(2)$ 結晶 の方位に依存して $\mathrm{K}-\mathrm{S}$ 関係からのずれ角が異なった界面を 形成する。

このような界面を応力軸上垂直方向にとり, 引張試験を行 うと, $\mathrm{K}-\mathrm{S}$ 関係を完全に満足する $\beta(1) / \gamma^{\prime}$ 界面では破壊せず, $\beta(2) / \gamma^{\prime}$ 界面で破壞する。この際の破壊応力と $\beta(2) / \gamma^{\prime}$ 界面 


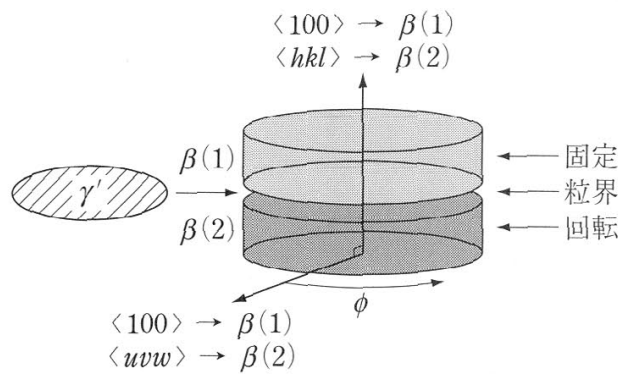

(a)

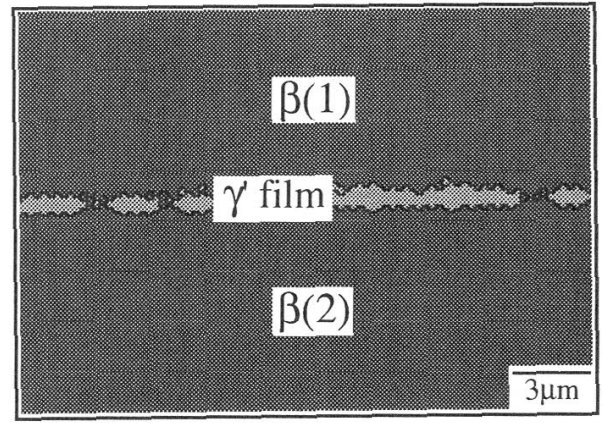

図 $6 \mathrm{NiAl}$ 双結晶 (a) と粒界析出相 (b).

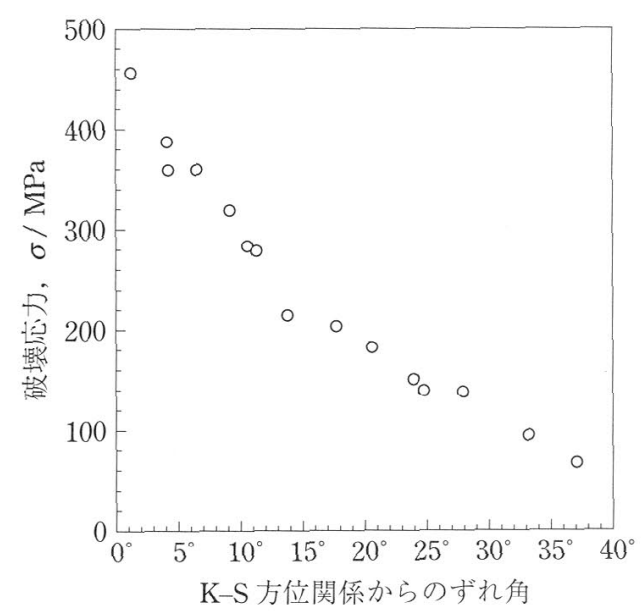

図 $7 \mathrm{NiAl}$ 双結晶に打訬る $\beta / \gamma^{\prime}$ 界面の $\mathrm{K}-\mathrm{S}$ 関係加らの ずれ角上破壊応力の関係.

の $\mathrm{K}-\mathrm{S}$ 関係からのずれ角との関係を図 7 に示す. K-S 関係 を満足する整合界面を有する場合の界面強度は大きく, $\mathrm{NiAl}$ の粒界破壊は著しく改善される。ずれ角の増加に伴っ て破壊応力は急速に低下し, 破壞は非整合な $\beta(2) / \gamma^{\prime}$ 界面に 扔いて起こる。従って，NiAlの粒界脆化抑制のためには， 粒界に析出するフィルム状 $\gamma^{\prime}$ 相と $\beta$ 相との界面の整合性を 高めることが重要となる。

さて, $\beta$ 相中に $\gamma^{\prime}$ 相が析出する際に, 形成される界面構造 は $\beta$ 粒界性格と密接な関係がある. 双結晶の結果は $\beta$ 相の $\{110\}$ 面々 $\gamma^{\prime}$ 相の $\{111\}$ 面が整合する形で析出しており，K$\mathrm{S}$ 関係を満足する界面の頻度を高めるためには， $\{110\} \beta$ 相 粒界の頻度を高める必要がある。Ni-36 at \% Al 多結晶を $1523 \mathrm{~K}$ で $\beta$ 単相化処理後, $1123 \mathrm{~K}$ で 1 時間の熱処理により 粒界に $\gamma^{\prime}$ 相を析出させた場合と, Ni-36 at \% Al 双結晶を $1523 \mathrm{~K}$ にて $\beta$ 単相化処理後 $1523 \mathrm{~K}$, 歪速度 $1 \times 10^{-3} \mathrm{~S}^{-1}$ で 真歪み 0.4 または 0.9 まで圧縮変形後 $1123 \mathrm{~K}$ で時効処理を行 い, $\gamma^{\prime}$ 相をフィルム状に析出させた場合の $\beta / \gamma^{\prime}$ 界面の $\mathrm{K}-\mathrm{S}$ 関係からのずれ角々存在頻度との関係を, 図 8 に示す(4). 単 純熱処理の場合に比べ，加工・熱処理を施した方が $\mathrm{K}-\mathrm{S}$ 関 係からのずれ角が小さい界面の割合が増す。この温度では $\beta$ 単相の変形は， $\{100\}\langle 100\rangle,\{100\}\langle 100\rangle$ および $\{110\}\langle 110\rangle$ すべりによって起こり，これらのすべりによる結晶回転の結 果, 〈111 $\rangle_{\beta}$ 集合組織が形成される。 その後の熱処理により 生成したフィルム状 $\gamma^{\prime}$ 相は $\beta$ 相の組織を反映して $\langle 110\rangle_{\gamma^{\prime}}$ 集 合組織を形成し，その結果 $\mathrm{K}-\mathrm{S}$ 関係からのずれ角の小さい $\beta / \gamma^{\prime}$ 界面の頻度が増加し, 粒界脆化抑制につながる。

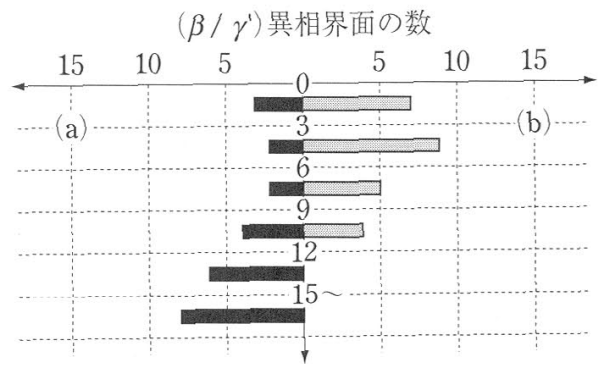

$\mathrm{K}-\mathrm{S}$ 方位関係からのずれ角度(度)

圖焼鈍

加工熱処理

図 $8 \mathrm{NiAl}$ 多結晶中に析出した $\gamma^{\prime}$ 相の $\beta / \gamma^{\prime}$ 界面の $\mathrm{K}-\mathrm{S}$ 関係からのずれ角と界面の数。

このように $\mathrm{bcc} \rightarrow \mathrm{fcc}$ 結晶構造变換の際の力位関係を念頭 に打いての適正な加工・熱処理プロセスの選択，たとえば単 結晶による方位制御圧延等による〈111 $\rangle_{\beta}$ 集合組織形成と相 変態過程の制御による整合異相界面の利用により, 高強度, 強勒性, 变形能に富む耐熱材料の開発が可能となるであろう.

\section{4.おわりに}

相変態, 析出を結晶構造変換の立場から捉え, その粒界性 格異存性を利用することにより，界面制御材料協調設計とも 呼ぶべき新たなマテリアルデザインの発展を期待する。

なお, 本研究は科学研究費特定領域研究 $(B)$ 複合機能化へ の材料協調設計の研究成果の一部である.

\section{文献}

（1）山口正治, 馬越佑吉：金属間化合物, 日刊工業新聞社, (1984).

(2) C. M. Magee: Phase Transformation, ASM, Metals Park, OH, (1969), 115-156.

(3) T. Sakata, H. Y. Yasuda and Y. Umakoshi: Acta Mater., $49(2001), 4231-4239$.

(4) T. Sakata, H. Y. Yasuda and Y. Umakoshi: STAM, in press.

(5) M. Ueda, H. Y. Yasuda and Y. Umakoshi: Acta Mater., $49(2001), 3421-3432$.

(6) M. Ueda, H. Y. Yasuda and Y. Umakoshi: Acta Mater., 49 (2001), 4251-4258.

(7) H. Onodera, H. Oka and I. Tamura: J. Japan. Inst. Metals, 42 (1978), 898-905.

( 8 ) D. Goodchild, W. T. Roberts and D. V. Wilson: Acta Metall, 18(1970), 1137-1145.

(9) R. Darolia: JOM, 43 (1991), 44-49.

(10) G. Kurdjumov and G. Sachs: Z. Phys., 64(1930), 325-343.

(11) S. Ochiai, I. Yamada and Y. Kojima: J. Japan. Inst. Metals, 54 (1990), 301-306. 